\title{
PENGARUH PENGENDALIAN INTERNAL, KESADARAN ANTI-FRAUD, INTEGRITAS, INDEPENDENSI, DAN PROFESIONALISME TERHADAP PENCEGAHAN KECURANGAN
}

\section{THE EFFECT OF INTERNAL CONTROL, ANTI-FRAUD AWARENESS, INTEGRITY, INDEPENDENCE, AND PROFESIONALISM TO FRAUD PREVENTION}

\author{
Dewi Novita Wulandari ${ }^{1}$, Muhammad Nuryatno ${ }^{2}$ \\ ${ }^{12}$ Program Studi Akuntansi FE Universitas Trisakti Jakarta \\ 12dewinovitawulandari@gmail.com, ${ }^{2}$ nanotrisakti2@gmail.com
}

\begin{abstract}
Abstrak
Opini audit merupakan pernyataan profesional auditor mengenai kewajaran informasi keuangan yang disajikan dalam laporan keuangan. Pemberian opini audit tidak terlepas dari potensi terjadinya kecurangan. Pencegahan kecurangan diperlukan untuk mencegah atau paling tidak mengendalikan timbulnya kecurangan dengan menciptakan kondisi yang mendorong upaya pencegahan kecurangan. Penelitian ini bertujuan untuk mendapatkan bukti pengaruh pengendalian internal, kesadaran antifraud, integritas, independensi, dan profesionalisme terhadap pencegahan kecurangan dalam pemeriksaan pengelolaan dan tanggung jawab keuangan negara. Data diperoleh melalui penyebaran kuesioner pada auditor Badan Pemeriksa Keuangan Republik Indonesia yang berada pada unit kerja Auditorat Utama Keuangan Negara I, V, dan VII. Jumlah sampel yang diperoleh sebanyak 149 responden. Metode penentuan sampel yang digunakan dalam penelitian ini adalah purposive sampling, sedangkan metode analisis data yang digunakan adalah analisis regresi linier berganda. Hasil penelitian ini menyimpulkan bahwa pengendalian internal, integritas, independensi, dan profesionalisme berpengaruh positif terhadap pencegahan kecurangan. Sedangkan kesadaran antifraud tidak berpengaruh positif terhadap pencegahan kecurangan.
\end{abstract}

Kata Kunci: pencegahan kecurangan, pengendalian internal, kesadaran anti-fraud, integritas, independensi, dan profesionalisme, opini audit.

\begin{abstract}
The audit opinion is the auditor's professional statement regarding the fairness of financial information presented in the financial statements. The provision of audit opinions is inseparable from the potential for fraud. Fraud prevention is needed to prevent or at least control the occurrence of fraud by creating conditions that encourage fraud prevention efforts. This study aims to obtain evidence of the effect of internal control, anti-fraud awareness, integrity, independence, and professionalism in fraud prevention in examining the management and responsibility of the state financial. The data was obtained through the distribution of questionnaires to the auditors of the Republic of Indonesia Supreme Audit Agency who work in the State Finance Main Auditor I, V, and VII units. The number of samples obtained was 149 respondents. The method of sample determination used in this study was purposive sampling, while the data analysis method used is multiple linear regression analysis. The results of this study conclude that internal control, integrity, independence, and professionalism had a positive effect on fraud prevention. While anti-fraud awareness has no effect on fraud prevention.
\end{abstract}

Keywords: fraud prevention, internal control, anti-fraud awareness, integrity, independence, and professionalism, audit opinion. 


\section{PENDAHULUAN}

\section{Latar Belakang}

Badan Pengawasan Keuangan dan Pembangunan (BPKP) (2008a) menjelaskan secara umum kecurangan mengandung tiga unsur penting yang terdiri atas perbuatan tidak jujur, niat atau kesengajaan, dan keuntungan yang merugikan orang lain. Sementara, pencegahan kecurangan merupakan upaya terintegrasi yang dapat menekan terjadinya faktor penyebab kecurangan. Seorang auditor dituntut untuk waspada terhadap setiap hal yang menunjukkan adanya kemungkinan kecurangan. Berdasarkan Standar Akuntansi Seksi 317 tentang Unsur Tindakan Pelanggaran Hukum oleh Klien, apabila terjadi unsur tindakan pelanggaran hukum (termasuk kecurangan), maka auditor akan mengumpulkan informasi tentang sifat pelanggaran, kondisi terjadinya pelanggaran, dan dampak potensinya terhadap laporan keuangan. Apabila kecurangan yang terjadi sangat material dan bisa mempengaruhi kewajaran laporan keuangan, maka auditor tidak dapat memberikan opini Wajar Tanpa Pengecualian (WTP).

Opini audit merupakan pernyataan profesional auditor mengenai kewajaran informasi keuangan yang disajikan dalam laporan keuangan. Terdapat empat jenis opini yang diberikan oleh auditor, yaitu WTP, Wajar Dengan Pengecualian (WDP), Tidak Wajar, dan Tidak Menyatakan Pendapat. Opini WTP merupakan predikat tertinggi dalam opini audit yang menunjukkan bahwa penyusunan laporan keuangan telah sesuai dengan prinsip pelaporan dan standar aturan.

Beberapa saat lalu, British Broadcasting Corporation Indonesia (2017) memberitakan adanya kasus dugaan suap terkait pemberian opini WTP terhadap anggaran Kementerian Desa Pembangunan Daerah Tertinggal dan Transmigrasi (Kemendes PDTT) oleh Badan Pemeriksa Keuangan (BPK). Dalam kasus ini, Komisi Pemberantasan Korupsi menetapkan empat tersangka, yaitu Inspektur Jenderal dan pejabat eselon III Kemendes PDTT, serta pejabat eselon I dan auditor BPK. Selain itu, republika.co.id (2017) memberitakan bahwa dalam periode tahun 2015 sampai dengan 27 Mei 2017, ada 23 auditor atau pejabat BPK yang terlibat dalam kasus suap, seperti suap untuk mendapatkan opini WTP atau WDP, suap untuk mengubah hasil temuan BPK, dan suap untuk membantu kelancaran proses audit.

Adanya risiko kecurangan dalam pemberian opini atas laporan keuangan menjadi alasan penting perlunya upaya dan strategi yang tepat dalam mencegah terjadinya kecurangan. Tanggung jawab untuk melakukan pencegahan kecurangan berada pada manajemen, pimpinan, dan otoritas-otoritas lain yang berkepentingan dalam pencapaian tujuan organisasi. Namun demikian, auditor juga turut berperan aktif dan bertanggung jawab untuk membantu manajemen untuk mencegah terjadinya kecurangan. Strategi pencegahan kecurangan diharapkan mampu mencegah atau paling tidak mengendalikan timbulnya kecurangan dengan menciptakan kondisi yang memudahkan dalam mendeteksi terjadinya kecurangan dan mendorong upaya pencegahan kecurangan.

\section{Kajian Literatur}

Teori keagenan oleh Jensen dan Meckling (1976) menjelaskan hubungan keagenan sebagai sebuah kontrak antara pemilik dan manajemen guna melakukan suatu jasa untuk kepentingan mereka dengan mendelegasikan wewenang pembuatan keputusan kepada manajemen. Teori ini bertujuan untuk menciptakan mekanisme yang menjamin keselarasan yang efisien antara kepentingan pemilik dan manajemen. Namun demikian, konflik kepentingan muncul karena adanya asimetri informasi antara kedua belah pihak, dimana manajemen lebih mengetahui kondisi perusahaan dibanding pemilik. Hal inilah yang dapat mendorong kemungkinan terjadinya kecurangan, sehingga diperlukan pihak ketiga yang independen yang memiliki peranan penting dalam memonitor kontrak dan mengurangi risiko kecurangan. Dalam konteks sektor publik dianalogikan bahwa pihak pemilik adalah rakyat, pihak manajemen adalah pemerintah, serta pihak ketiga yang independen adalah BPK. 
Pencegahan kecurangan didefinisikan oleh BPKP (2008a) sebagai upaya terintegrasi yang dapat menekan terjadinya faktor penyebab kecurangan, yaitu peluang, dorongan, dan rasionalisasi. Tujuan pencegahan kecurangan antara lain mencegah terjadinya kecurangan pada semua lini organisasi, menangkal pelaku potensial, mempersulit gerak langkah pelaku kecurangan, mengidentifikasi kegiatan berisiko tinggi dan kelemahan pengendalian, serta melakukan tuntutan dan penjatuhan sanksi pada pelaku kecurangan. Adapun metode pencegahan kecurangan yang dapat dilakukan, meliputi penetapan kebijakan anti-fraud, menciptakan prosedur pencegahan baku, membangun struktur organisasi dengan pengendalian yang baik, merancang teknik pengendalian yang efektif, dan menumbuhkan kepekaan terhadap kecurangan.

Pengendalian internal yang efektif sangat diperlukan dalam melaksanakan strategi pencegahan, dengan dibangun dan diimplementasikannya pengendalian internal, diharapkan dapat menjadi daya tangkal atas penyelewengan yang dilakukan. COSO (2013) menjelaskan bahwa pengendalian internal merupakan suatu proses yang dipengaruhi oleh dewan direksi, manajemen, dan pihak lain yang dirancang untuk memberikan keyakinan yang memadai dalam pencapaian tujuan terkait dengan aktivitas operasi, pelaporan, dan kepatuhan. Ketiga tujuan tersebut dapat dicapai dengan memperhatikan komponen pengendalian internal, yaitu lingkungan pengendalian, penilaian risiko, aktivitas pengendalian, informasi dan komunikasi, serta aktivitas pemantauan.

Tuanakotta (2012) menyebutkan bahwa terdapat konsep lain dalam upaya pencegahan kecurangan selain pengendalian internal, yaitu menanamkan kesadaran tentang adanya kecurangan (fraud awareness). Kesadaran anti-fraud menurut Bank Indonesia (2011) merupakan suatu upaya untuk menumbuhkan kesadaran mengenai pentingnya upaya pencegahan kecurangan oleh semua pihak dalam organisasi. Melalui kepemimpinan yang baik dan didukung dengan kesadaran anti-fraud yang tinggi diharapkan dapat menumbuhkan kepedulian semua pihak dalam organisasi terhadap pencegahan kecurangan. BPKP (2008a) menyatakan bahwa kecurangan dapat dicegah apabila organisasi memiliki karyawan yang berpengalaman dan mempunyai kemampuan berpikir analitis dan logis, cerdas, tanggap, berpikir cepat, dan terperinci. Bersumber pada Statement on Auditing Standard Nomor 99, American Institute of Certified Public Accountant (AICPA) (2002) dalam Management AntiFraud and Controls mengungkapkan dimensi pengukuran yang digunakan dalam mendeteksi dan mencegah kecurangan, antara lain menciptakan dan memelihara budaya kejujuran dan etika yang tinggi, melaksanakan evaluasi atas proses anti-fraud dan pengendalian, serta mengembangkan proses pengawasan yang memadai

Pelaksanaan audit pada sektor pemerintahan merupakan suatu hal penting sebagai bentuk pertanggungjawaban pemerintah kepada masyarakat, sehingga setiap auditor di sektor pemerintah mempunyai kewajiban etis untuk menjaga dan melindungi kepentingan masyarakat. Masyarakat mengharapkan lembaga pemeriksa dan auditor untuk melaksanakan audit sesuai dengan kode etik yang berlaku. Dengan adanya kode etik diharapkan para auditor mampu menjaga integritas, independensi, dan profesionalisme, serta mengetahui perbuatan apa saja yang benar atau salah, perbuatan apa yang harus dilakukan, dan apa yang harus dihindari dalam pelaksanaan audit.

SPKN BPK (2017) menjelaskan bahwa integritas adalah mutu, sifat, atau keadaan yang menunjukkan kesatuan yang utuh, dimilikinya sifat jujur, kerja keras, serta kompetensi yang memadai. Kode Perilaku Profesional AICPA dalam Arens dkk. (2012) dan Prinsip Etika Profesi Ikatan Akuntan Indonesia dalam Mulyadi (2006) menjelaskan bahwa untuk mempertahankan dan memperluas kepercayaan publik, auditor harus melaksanakan seluruh tanggung jawab profesionalnya dengan tingkat integritas tinggi. BPKP (2008b) menjelaskan bahwa auditor dituntut untuk memiliki kepribadian yang dilandasi sikap jujur, berani, 
bijaksana, dan bertanggung jawab untuk membangun kepercayaan guna memberikan dasar

bagi pengambilan keputusan yang handal.

Independensi menurut SPKN BPK (2017) adalah suatu sikap dan tindakan dalam melaksanakan audit untuk tidak memihak kepada siapapun dan tidak dipengaruhi oleh siapapun. Mulyadi (2006) menjelaskan bahwa independensi diperlukan oleh auditor untuk memperoleh kepercayaan dari klien sehingga akan meningkatkan kredibilitas laporan keuangan. Adapun indikator independensi profesional dalam Sawyer (2006) terdiri dari independensi atas program audit, verifikasi, dan pelaporan.

Menurut SPKN BPK (2017), profesionalisme adalah kemampuan, keahlian, dan komitmen profesi dalam menjalankan tugas disertai prinsip kehati-hatian, ketelitian, dan kecermatan, serta berpedoman kepada standar dan ketentuan peraturan perundang-undangan. Sawyer (2006) menjelaskan bahwa mendorong terbentuknya sikap patuh terhadap standar profesional dan kode etik akan menimbulkan intensi untuk melaporkan opini yang objektif, tidak bias, tidak dibatasi, dan melaporkan masalah ada adanya. Kode Perilaku Profesional AICPA dalam Arens dkk. (2012) menyebutkan prinsip profesional terdiri dari tanggung jawab, kepentingan publik, keseksamaan, serta ruang lingkup dan sifat jasa.

\section{Hipotesis}

Yuniarti (2017) menyimpulkan bahwa pengendalian internal berpengaruh positif terhadap pencegahan kecurangan. Dimitrijevic (2015) menyimpulkan bahwa pengendalian internal berpengaruh terhadap pencegahan kecurangan. Strategi pencegahan kecurangan berkaitan dengan cara mengendalikan faktor pendorong timbulnya kecurangan dengan menciptakan kondisi yang mampu mendorong upaya pencegahan kecurangan, sehingga untuk melaksanakan strategi ini, pengendalian internal harus diterapkan secara efektif. Terjadinya kecurangan dapat dideteksi dan dicegah secara dini dengan pengendalian internal yang baik. Albrecht dkk. (2012) menyatakan bahwa memiliki pengendalian internal yang baik merupakan cara yang digunakan secara luas oleh banyak pihak untuk mencegah kecurangan. Hal ini dapat diartikan bahwa semakin baik penerapan pengendalian internal, maka pencegahan kecurangan dalam organisasi akan semakin meningkat.

\section{$\mathrm{H}_{1}$ : Pengendalian Internal berpengaruh positif terhadap pencegahan kecurangan.}

Kesadaran anti-fraud berpengaruh positif terhadap pencegahan kecurangan, diungkapkan dalam penelitian Yuniarti (2017). Siregar (2015) mengungkapkan bahwa kesadaran anti-fraud berpengaruh terhadap pencegahan kecurangan. Kesadaran anti-fraud merupakan upaya untuk menumbuhkan kesadaran mengenai pentingnya pencegahan kecurangan oleh semua pihak di organisasi. Melalui kesadaran anti-fraud yang tinggi diharapkan dapat menumbuhkan kepedulian dan kepekaan semua pihak terhadap bahaya kecurangan dan pengendalian yang diperlukan untuk mencegah kecurangan.

\section{$\mathrm{H}_{2}$ : Kesadaran anti-fraud berpengaruh positif terhadap pencegahan kecurangan.}

Ramadhaniyati (2014) menyimpulkan bahwa integritas berpengaruh positif dalam mencegah kecurangan. Sab u (2013) menyimpulkan bahwa integritas berpengaruh dalam mencegah kecurangan. Risiko kecurangan dapat diminimalisir dengan adanya sikap integritas auditor, karena integritas berkaitan dengan kejujuran dan tanggung jawab auditor. Apabila auditor memiliki sikap integritas tinggi maka auditor tersebut telah melaksanakan pekerjaannya sesuai dengan etika. Sikap jujur auditor tersebut menunjukkan hasil audit yang benar.

\section{$\mathbf{H}_{3}$ : Integritas berpengaruh positif terhadap pencegahan kecurangan.}

Windasari (2016) dan Ramadhaniyati (2014) menyatakan bahwa independensi auditor berpengaruh positif dalam mencegah kecurangan. Zhou (2012) menyatakan bahwa 
independensi berpengaruh terhadap pencegahan kecurangan. Seorang auditor yang profesional harus memiliki independensi untuk memenuhi kewajiban profesionalismenya. Jika seorang auditor bersikap independen, maka auditor akan memberi penilaian audit yang dilakukan, tanpa memiliki beban apapun terhadap pihak manapun sehingga terhindar dari konflik kepentingan yang berisiko menimbulkan kecurangan.

\section{$\mathbf{H}_{4}$ : Independensi berpengaruh positif dalam pencegahan kecurangan.}

Windasari (2016) mengungkapkan bahwa profesionalisme auditor berpengaruh positif dalam mencegah kecurangan. Zhou (2012) mengungkapkan bahwa profesionalisme berpengaruh dalam mencegah kecurangan. Profesionalisme seorang auditor sangat dibutuhkan dalam mencegah kecurangan, karena semakin tinggi profesionalisme seorang auditor maka kebebasan auditor akan semakin terjamin. Auditor yang profesional akan mengungkapkan kecurangan apabila menemukan adanya tindak kecurangan, sehingga tindakan kecurangan dapat dicegah.

\section{$\mathrm{H}_{5}$ : Profesionalisme berpengaruh positif terhadap pencegahan kecurangan.}

\section{METODE}

\section{Rancangan Penelitian}

Sifat penelitian ini adalah pengujian hipotesis, artinya penelitian dilakukan untuk memahami pengaruh atau menentukan perbedaan pengaruh antar variabel dalam penelitian. Data penelitian ini adalah data primer yang dikumpulkan menggunakan kuesioner yang diperoleh dari situasi lingkungan riil dengan tingkat intervensi minimal. Populasi dalam penelitian ini adalah auditor pada Kantor BPK Pusat. Metode pengambilan sampel yang digunakan adalah purposive sampling dengan kriteria auditor pada Auditorat Utama Keuangan Negara (AKN) I, V, dan VII. Metode analisis dalam penelitian ini menggunakan analisis regresi linier berganda.

\section{Definisi Operasional Variabel}

Pencegahan kecurangan merupakan upaya terintegrasi yang dapat menekan terjadinya faktor penyebab kecurangan. Variabel pencegahan kecurangan diukur dengan menggunakan indikator yang bersumber dari BPKP (2008a), yaitu penetapan kebijakan anti-fraud, menciptakan prosedur pencegahan baku, membangun struktur organisasi dengan pengendalian yang baik, merancang teknik pengendalian yang efektif, dan menumbuhkan kepekaan terhadap kecurangan.

Pengendalian internal merupakan suatu proses yang dipengaruhi oleh dewan direksi, manajemen, dan pihak lain yang dirancang untuk memberikan keyakinan yang memadai dalam pencapaian tujuan organisasi. Variabel pengendalian internal diukur dengan menggunakan indikator yang bersumber dari COSO (2013), yaitu lingkungan pengendalian, penilaian risiko, aktivitas pengendalian, informasi dan komunikasi, serta aktivitas pemantauan.

Kesadaran anti-fraud sebagai upaya untuk menumbuhkan kesadaran mengenai pentingnya upaya pencegahan kecurangan oleh semua pihak dalam organisasi. Variabel kesadaran anti-fraud diukur dengan menggunakan indikator yang bersumber dari AICPA (2002), yaitu menciptakan dan memelihara budaya kejujuran dan etika yang tinggi, melaksanakan evaluasi atas proses anti-fraud dan pengendalian, serta mengembangkan proses pengawasan yang memadai.

Integritas adalah mutu, sifat, atau keadaan yang menunjukkan kesatuan yang utuh, dimilikinya sifat jujur, kerja keras, serta kompetensi yang memadai. Variabel integritas diukur dengan menggunakan indikator yang bersumber dari BPKP (2008b) dan disesuaikan dengan SPKN BPK (2017), yaitu sikap jujur, berani, bijaksana, dan bertanggung jawab. 
Independensi adalah suatu sikap dan tindakan dalam melaksanakan audit untuk tidak memihak kepada siapapun dan tidak dipengaruhi oleh siapapun. Variabel independensi diukur dengan menggunakan indikator mengacu pada indikator yang bersumber dari Sawyer (2006) dan disesuaikan dengan SPKN BPK (2017), yaitu independensi dalam program audit, verifikasi, dan pelaporan.

Profesionalisme adalah kemampuan, keahlian, dan komitmen profesi dalam menjalankan tugas disertai prinsip kehati-hatian, ketelitian, dan kecermatan, serta berpedoman kepada standar dan ketentuan peraturan perundang-undangan. Variabel profesionalisme diukur dengan menggunakan indikator yang bersumber dari Arens dkk. (2012) dan disesuaikan dengan SPKN BPK (2017), yaitu tanggung jawab, kepentingan publik, keseksamaan, serta ruang lingkup dan sifat jasa.

Skala pengukuran yang digunakan dalam penelitian ini adalah skala likert. Ukuran yang digunakan untuk menilai jawaban ada lima poin, yaitu:

$1=$ Sangat Tidak Setuju (STS)

2 = Tidak Setuju $(\mathrm{TS})$

$3=\operatorname{Netral}(\mathrm{N})$

$4=$ Setuju $(\mathrm{S})$

$5=$ Sangat Setuju $(\mathrm{SS})$

\section{HASIL DAN PEMBAHASAN}

Pengaruh variabel pengendalian internal, kesadaran anti-fraud, integritas, independensi, dan profesionalisme terhadap pencegahan kecurangan dapat dijelaskan melalui tabel berikut.

Tabel 1. Hasil Uji Analisis Regresi Berganda

\begin{tabular}{ccccccc}
\hline \multirow{2}{*}{ Model } & \multicolumn{2}{c}{$\begin{array}{c}\text { Unstandardized } \\
\text { Coefficients }\end{array}$} & $\begin{array}{c}\text { Standardized } \\
\text { Coefficients }\end{array}$ & t & \multirow{2}{*}{ Sig. } \\
\cline { 2 - 5 } & B & Std. Error & Beta & & \\
\hline \multirow{4}{*}{1 (Constant) } & 2,117 & 1,579 & & 1,341 & 0,182 \\
& Pengendalian Internal & 0,249 & 0,058 & 0,304 & 4,275 & 0,000 \\
Kesadaran Anti-Fraud & 0,065 & 0,060 & 0,075 & 1,079 & 0,282 \\
& Integritas & 0,125 & 0,046 & 0,199 & 2,752 & 0,007 \\
& Independensi & 0,149 & 0,055 & 0,174 & 2,725 & 0,007 \\
Profesionalisme & 0,321 & 0,068 & 0,268 & 4,721 & 0,000 \\
\hline
\end{tabular}

Sumber: Data primer (diolah), 2018.

Hipotesis pertama adalah pengendalian internal berpengaruh positif terhadap pencegahan kecurangan. Variabel ini memiliki nilai signifikansi sebesar $0,000<0,05$ dengan nilai koefisien regresi (B) sebesar 0,249 . Hal ini menunjukkan bahwa $\mathrm{H}_{1}$ diterima, artinya secara parsial pengendalian internal berpengaruh positif dan signifikan terhadap pencegahan kecurangan. Strategi pencegahan kecurangan merupakan serangkaian program yang dirancang untuk mengendalikan faktor pendorong timbulnya kecurangan dengan menciptakan kondisi yang memudahkan dalam mendeteksi terjadinya kecurangan dan mendorong upaya pencegahan kecurangan, salah satunya dengan penerapan pengendalian internal yang efektif. Terjadinya kecurangan dapat dideteksi dan dicegah secara dini dengan pengendalian internal yang baik. Semakin efektif pengendalian internal yang diterapkan, maka kemungkinan untuk terjadinya kecurangan dapat diminimalisir. Hasil penelitian ini sejalan dengan penelitian Yuniarti (2017) yang menyatakan bahwa pengendalian internal berpengaruh positif terhadap pencegahan kecurangan dan Dimitrijevic (2015) yang menyatakan bahwa pengendalian internal berpengaruh terhadap pencegahan kecurangan. 
Hipotesis kedua adalah kesadaran anti-fraud berpengaruh positif terhadap pencegahan kecurangan. Variabel ini memiliki nilai signifikansi sebesar $0,282>0,05$ dengan nilai koefisien regresi (B) sebesar 0,065. Hal ini menunjukkan bahwa $\mathrm{H}_{2}$ ditolak, artinya secara parsial kesadaran anti-fraud tidak berpengaruh positif dan signifikan terhadap pencegahan kecurangan. Kesadaran anti-fraud memang dinilai cukup penting dalam mencegah dan meminimalisir risiko kecurangan. Namun dalam penelitian ini, kesadaran anti-fraud tidak mempengaruhi auditor dalam mencegah kecurangan. Hal ini dikarenakan kebijakan antifraud yang diterapkan lebih bersifat partisipatif dan tidak menekankan pengawasan dengan segala implementasinya. Hasil penelitian ini tidak sejalan dengan penelitian Yuniarti (2017) yang menyatakan bahwa kesadaran anti-fraud berpengaruh positif terhadap pencegahan kecurangan dan Siregar (2015) yang menyatakan bahwa kesadaran anti-fraud berpengaruh terhadap pencegahan kecurangan.

Hipotesis ketiga adalah integritas berpengaruh positif terhadap pencegahan kecurangan.

Variabel ini memiliki nilai signifikansi sebesar $0,007<0,05$ dengan nilai koefisien regresi (B) sebesar 0,125. Hal ini menunjukkan bahwa $\mathrm{H}_{3}$ diterima, artinya secara parsial integritas berpengaruh positif dan signifikan terhadap pencegahan kecurangan. Seorang auditor yang memiliki integritas yang tinggi, dimana auditor menjaga kepercayaan publik, sifat jujur, kerja keras, serta kompetensi yang memadai, maka akan berpengaruh positif terhadap pencegahan kecurangan. Hasil penelitian ini sejalan dengan penelitian Ramadhaniyati (2014) yang menyatakan bahwa integritas berpengaruh positif dalam mencegah kecurangan dan Sab u (2013) yang menyatakan bahwa integritas berpengaruh dalam mencegah kecurangan.

Hipotesis keempat adalah independensi berpengaruh positif terhadap pencegahan kecurangan. Variabel ini memiliki nilai signifikansi sebesar $0,007<0,05$ dengan nilai koefisien regresi (B) sebesar 0,149. Hal ini menunjukkan bahwa $\mathrm{H}_{4}$ diterima, artinya secara parsial independensi berpengaruh positif dan signifikan terhadap pencegahan kecurangan. Seorang auditor yang mempunyai independensi yang tinggi akan lebih memikirkan tujuan dan tidak mudah dikendalikan oleh pihak lain dalam menemukan kecurangan saat melakukan pemeriksaan laporan keuangan. Hasil penelitian ini sejalan dengan penelitian Windasari (2016) dan Ramadhaniyati (2014) yang menyatakan bahwa independensi auditor berpengaruh positif dalam mencegah kecurangan. Zhou (2012) yang menyatakan bahwa independensi berpengaruh terhadap pencegahan kecurangan.

Hipotesis kelima adalah profesionalisme berpengaruh positif terhadap pencegahan kecurangan. Variabel ini memiliki nilai signifikansi sebesar $0,000<0,05$ dengan nilai koefisien regresi (B) sebesar 0,321. Hal ini menunjukkan bahwa $\mathrm{H}_{5}$ diterima, artinya secara parsial profesionalisme berpengaruh positif dan signifikan terhadap pencegahan kecurangan. Seorang auditor yang profesional memberikan opini yang objektif, tidak bias, tidak dibatasi, dan melaporkan masalah apa adanya bukan melaporkan sesuai keingingan atau kepentingan pihak lain. Hasil penelitian ini sejalan dengan penelitian Windasari (2016) yang menyatakan bahwa profesionalisme auditor berpengaruh positif pada pencegahan kecurangan dan Zhou (2012) yang menyatakan bahwa profesionalisme berpengaruh dalam mencegah kecurangan.

\section{KESIMPULAN}

Berdasarkan hasil dari analisis dan pembahasan, maka dapat disimpulkan bahwa pengendalian internal, integritas, independensi, dan profesionalisme berpengaruh positif terhadap pencegahan kecurangan. Hal ini berarti menurut persepsi auditor BPK, semakin tinggi pengendalian internal, integritas, independensi, dan profesionalisme maka pencegahan kecurangan akan semakin meningkat. Sementara itu, kesadaran anti-fraud tidak berpengaruh positif terhadap pencegahan kecurangan. Hal ini berarti menurut persepsi auditor BPK, kesadaran anti-fraud tidak mempengaruhi auditor dalam mencegah kecurangan 
Keterbatasan penelitian ini adalah responden yang menjadi target sampel dalam penelitian ini terbatas pada tiga dari tujuh unit kerja AKN di Kantor BPK Pusat, sehingga penelitian ini belum mencerminkan persepsi auditor BPK secara keseluruhan.

Penelitian ini diharapkan dapat mendorong arah penelitian selanjutnya untuk lebih spesifik melakukan penelitian terkait hal-hal yang dapat mempengaruhi pencegahan kecurangan dalam pemeriksaan pengelolaan dan tanggung jawab keuangan negara.

\section{DAFTAR PUSTAKA}

Albrecht, W. Steve, Conan C. Albrecht, Chad O. Albrecht, \& Mark F. Zimbelman. (2012). Fraud Examination. $4^{\text {th }}$ Edition. Mason: South Western Cengage Learning.

American Institute of Certified Public Accountant (AICPA). (2002). Statement on Auditing Standards No.99, Consideration of Frauds in a Financial Statement Audit. Management Anti Fraud Programs and Controls. New York: AICPA, Inc.

Arens, Alvin A, Randal J. Elder, \& Mark S. Beasley. (2012). Auditing and Assurance Service; An Integrated Approach. $14^{\text {th }}$ Edition. New Jersey: Pearson Prentice Hall.

Badan Pemeriksa Keuangan (BPK). (2016). Peraturan Badan Pemeriksa Keuangan Republik Indonesia Nomor 3 Tahun 2016 tentang Kode Etik Badan Pemeriksa Keuangan.

(2017). Peraturan Badan Pemeriksa Keuangan Republik Indonesia Nomor 1 Tahun 2017 tentang Standar Pemeriksaan Keuangan Negara.

Badan Pengawasan Keuangan dan Pembangunan (BPKP). (2008a). Fraud Auditing. Edisi Kelima. Jakarta: Pusat Pendidikan dan Pelatihan Pengawasan BPKP.

(2008b). Kode Etik dan Standar Audit. Edisi Kelima. Jakarta: Pusat Pendidikan dan Pelatihan Pengawasan BPKP.

Bank Indonesia. (2011). Surat Edaran Bank Indonesia No. 13/28/DPNP tentang Penerapan Strategi Anti Fraud bagi Bank Umum.

BBC Indonesia. (2017). Penangkapan dalam Kasus Kemendes: Ada apa dengan BPK?. http://www.bbc.com (diakses 28 April 2018).

Committee of Sponsoring Organizations of Teadway Commission (COSO). (2013). Internal Control-Integrated Framework. www.coso.org/IC.htm (diakses 6 April 2018).

Dimitrijevic, Dragomir, Vesna Milovanovic, Vladimir Stancic. (2015). The Role of A Company's Internal Control System In Fraud Prevention. Financial Internet Quarterly „e-Finanse”, 11: 34-44.

Ghozali, Imam. (2016). Aplikasi Analisis Multivariete dengan Program IBM SPSS 23. Edisi 8. Semarang: Badan Penerbit Universitas Diponegoro.

Ikatan Akuntan Indonesia. (2001). Standar Pemeriksaan Akuntan Publik. SA Seksi 317. Unsur Tindakan Pelanggaran Hukum oleh Klien.

Jensen, Michael C., William H. Meckling. (1976). Theory of The Firm: Managerial Behavior, Agency Costs and Ownership Structure. Journal of Financial Economics, 3 (10): 305-360. 
Mulyadi. (2006). Auditing. Yogyakarta: STIE YKPN.

Ramadhaniyati, Yayuk, Nur Hayati. (2014). Pengaruh Profesionalisme, Motivasi, Integritas, dan Independensi Satuan Pengawasan Internal dalam Mencegah Kecurangan (Fraud) di Lingkungan Perguruan Tinggi Negeri. JAFFA, 02 (10): 101-114.

Republik Indonesia. (2004). Undang-Undang Republik Indonesia Nomor 15 Tahun 2004 tentang Pemeriksaan Pengelolaan dan Tanggung Jawab Keuangan Negara. Lembaran Negara Republik Indonesia Tahun 2004 Nomor 66. Jakarta: Sekretariat Negara.

(2006). Undang-Undang Republik Indonesia Nomor 15 Tahun 2006 tentang Badan Pemeriksa Keuangan. Lembaran Negara Republik Indonesia Tahun 2006 Nomor 85. Jakarta: Sekretariat Negara

(2008). Peraturan Pemerintah Republik Indonesia Nomor 60 Tahun 2008 tentang Sistem Pengendalian Intern Pemerintah. Lembaran Negara Republik Indonesia Tahun 2008 Nomor 127. Jakarta: Sekretariat Negara.

Sab u, Elena Monica, Cleopatra Şendroiu, Florinel Marian Sg rdea. (2013). Corporate AntiFraud Strategies - Ethic Culture and Occupational Integrity. Cross-Cultural Management Journal, 15: 59-65.

Sawyer, B. Lawrence, Mortimer A. Dittenhofer, \& James H. Scheiner. (2005). Internal Auditing. Edisi 5. Jakarta: Salemba Empat.

Sekaran, Uma, Roger Bougie. (2017). Metode Penelitian untuk Bisnis: Pendekatan Pengembangan-Keahlian. Edisi 6. Jakarta: Salemba Empat.

Siregar, Veronica Siregar, Bayu Tenoyo. (2015). Fraud Awareness Survey of Private Sector in Indonesia. Journal of Financial Crime, 22: 329-346.

Singleton, Tommie, Aaron Singleton, Jack Bologna, and Robert Lindquist. (2010). Fraud Auditing and Forensic Accounting. $4^{\text {th }}$ Edition.

Tuanakotta, Theodorus. M. (2010). Akuntansi Forensik dan Audit Investigatif. Edisi 2. Jakarta: Salemba Empat.

Watts, Ross L., Jerold L. Zimmerman. (1990). Positive Accounting Theory: A Ten Year Perspective. The Accounting Review, 65 (1):131-156.

Windasari, Made Yunita, Gede Juliarsa. (2016). Pengaruh Kompetensi, Independensi, dan Profesionalisme Auditor Internal dalam Mencegah Kecurangan pada BPR di Kabupaten Badung. E-Jurnal Akuntansi Universitas Udayana. 17.3 (12): 1924-1952.

Wiryono, Singgih, Teguh Firmansyah. (2017). ICW: 23 Auditor BPK Terlibat Kasus Suap dalam Dua Tahun Terakhir. http://nasional.republika.co.id (diakses 6 Maret 2018).

Yuniarti, Rozmita Dewi. (2017). The Effect of Internal Control and Anti-Fraud Awareness on Fraud Prevention (A Survey on Inter-Governmental Organizations). Journal of Economics, Business, and Accountancy Ventura, 20 (7): 113-124.

Zhou, Yuhao. (2012). The Role of External Auditors in Detecting and Reporting Corporate Fraud in Public Listed Companies in China. International Journal of Business Administration, 3 (1): 2-15. 